\title{
Spatial data-based closure costing integrated with life-of-mine planning: a key enabler facilitating value realisation
}

\author{
P Kumari Anglo American PLC, South Africa \\ M Cooper Deswik Mining Consultants Pty Ltd, South Africa
}

\begin{abstract}
Knowing with reasonable accuracy the life-of-mine (LOM) closure cost estimate at the initial stages for operating mines can significantly help with efficient operational planning and ensure a sustainable closurea key principle of integrated mine closure planning. The conventional, quantity surveying-based closure costing methods work reasonably well for infrastructure demolition costs compared with the landform design costs. Utilising spatial data modelling tools that allow for an accurate quantification of material movement volumes is an attractive improvement on the existing methods. Spatial models can be built to calculate closure costs from first principles. This provides a clear understanding of significant cost categories and the underlying cost drivers, resulting in accurate cost estimates. In addition, these models enable users with an efficient way of comparing multiple landform designs for any given optimisation criteria (e.g. legal, regulatory, environmental and financial constraints). Coupled with the resource management and scheduling modules, the tool enables direct integration of closure planning into the LOM planning and provides detailed LoM schedules and cash flow. Easy opportunity and risk analyses of various planning options assist in designing an optimised concurrent rehabilitation cash flow over the operational LoM, ensuring that the residual liability at the end of the life is minimal when the mine profits would usually decline.

This paper presents a case study of a large open pit hard rock mining operation, the Anglo American-owned Mogalakwena platinum mine in South Africa, where the closure cost estimate was significantly improved in accuracy when using a digital terrain model (DTM) in a Deswik closure costing platform (Enviro tool and modules). Built from first principles and with detailed resource allocations (incorporating equipment/labour efficiencies and schedules), the 3D costing model highlighted that reshaping of certain waste rock dump slopes into final landform would have significant material movement costs due to constrained dumping space at the mine-enabling the mine to consider a revised LoM waste placement strategy and concurrent rehabilitation plan. This paper also discusses the challenges in establishing a flexible and robust 3D costing model, and shares learnings from the Mogalakwena project.
\end{abstract}

Keywords: closure cost, integrated closure planning, life-of-mine (LoM) planning, spatial data

\section{$1 \quad$ Introduction}

There are numerous reasons (e.g. financial, technical, social and political) for a mine to go into closure, some of which can be controlled and planned. The repercussions of unplanned closure are well known and are evident in the form of legacy sites across the world. Uncertainties and risks associated with closure should typically reduce over an operation's lifecycle, leaving few or no surprises at the end of life (ICMM 2008; Bocking 2010). However, as a mining operation progresses and gets closure to its end of life, the number of available closure solutions diminishes, and the cost of remaining opportunities or solutions increases (Slingerland \& Wilson 2015). Therefore, the longer the remaining life of an operation, the better the chances of realising value through an integrated planning process. The Integrated Closure Planning System (ICPS) developed by Anglo American is a system that combines the various mine planning regimes-internal and external requirements, financial considerations and systems from a people, process and technology 
perspective. Applied over the lifecycle of operations, the system ensures Anglo American operations optimise the use of its resources and leaves a positive and sustainable legacy for the host communities post-closure (Grant \& Lacy 2016). These opportunities can range from rethinking the entire mining sequence to placing the waste and growth media optimally given the constraints and available opportunities. In addition to cost reduction and optimal closure cash flow, opportunities for local or regional socio-economic development can be realised in the process.

A model that can accurately estimate the cost of achieving an optimal post-closure landform design by enabling multiple production scenario/opportunities analyses with ease in a reasonable time frame is essential for the value realisation of the ICPS. Deswik Mining Consultants Pty Ltd has developed a CAD-based tool that combines the benefits of three key components in closure cost estimation-CAD for 3D spatial data modelling, optimised resource allocation, and task scheduling. The use of 3D spatial data to model the closure costs allows for the following:

- Accurate volumetric and surface area measurements-a key physical measurement inputs in the cost model.

- Convenient cost-benefit analysis of multiple landform designs - testing of various opportunities and constraints. Figure 1 illustrates the importance of making a value decision based on integrated planning by optimising multiple production and closure scenarios instead of working in silos.

- Enables multiple specialist analyses on the final landform designs such as geotechnical stability assessment, erosion study, hydrological analyses and environmental impact assessment.

- The costing model is scalable allowing consideration of a specific area as well as the entire mine.

- Visualisation is the key-convenient visualisation of spatial and temporal changes and costing heat maps etc. to draw people's attention to the areas of concern or interest.

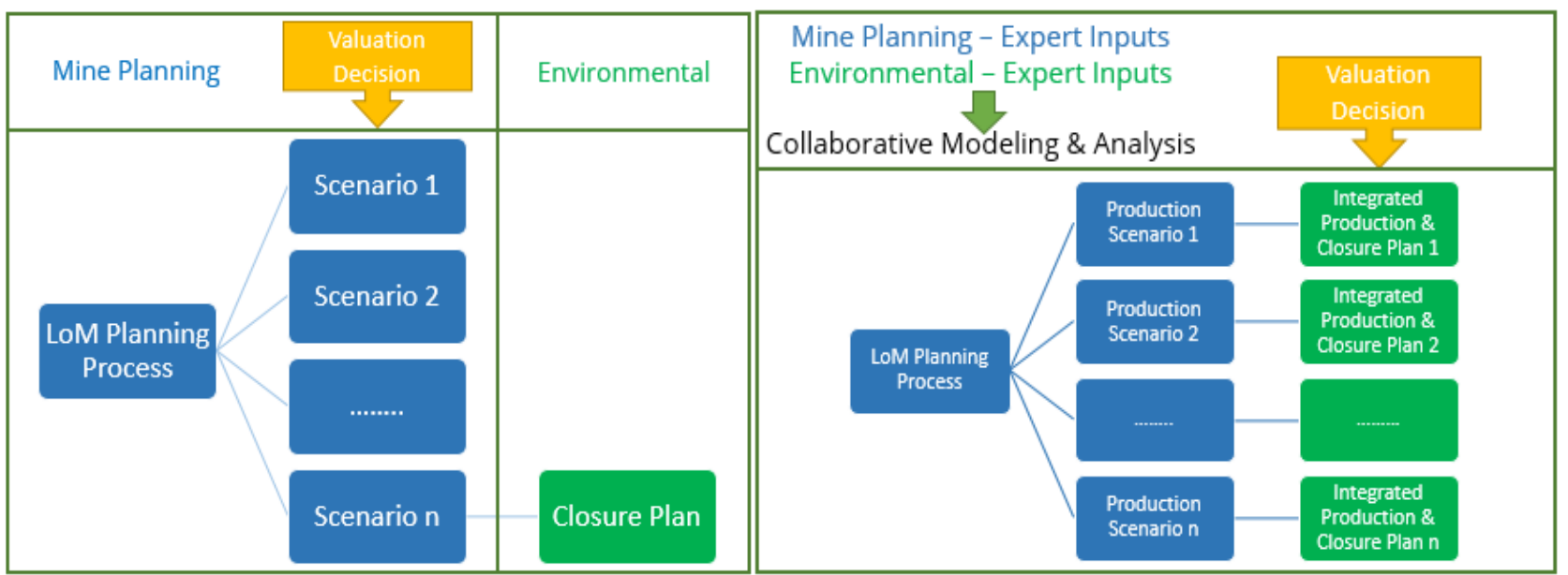

(a)

(b)

Figure 1 Mine planning in silos (a) versus integrated planning (b)

In addition, the inclusion of resource allocation and optimisation along with the scheduling component have the following advantages:

- Accurate assessment of owner's costs by optimising the resources (equipment, labour, etc.) required to achieve a specific landform design.

- Task scheduling using equipment efficiencies, cycle times, work shifts and maintenance schedules (i.e. availability) provides a reasonable estimate of the length of the closure period to achieve final landform. 
This paper presents an example of the Anglo American-owned open pit Mogalakwena platinum mine in South Africa that has a remaining life of more than 50 years. The objective of this paper is to describe the cost estimation method used to assess the immediate and planned, or LoM, closure costs at Mogalakwena and share the benefits and learnings of the study.

\section{Methodology}

A good closure cost estimate requires a robust model and expertise. Various methodologies exist to achieve a closure cost estimate, which vary depending on the reporting and planning requirements. However, the underlying principle is the same (i.e. quantity estimation). Liability estimates rely on models and are therefore sensitive to the assumptions used to construct them and to the input data provided. Determination of the scope, limitations, inclusion, exclusions, physical measurements, accounting treatments and degree to which probability, uncertainty and contingency are applied to estimates are all an essential part of the development of estimating processes (Haymont 2012). The Deswik CAD model used in estimating the closure costs at Mogalakwena allows for a first principle cost build-up. Within the Deswik CAD platform, users can create a process flow map that essentially is a set of executable instructions to achieve the cost estimation. Figure 2 illustrates the process flow used for the physical closure cost estimate (i.e. infrastructure demolition, landform reshaping and rehabilitation).

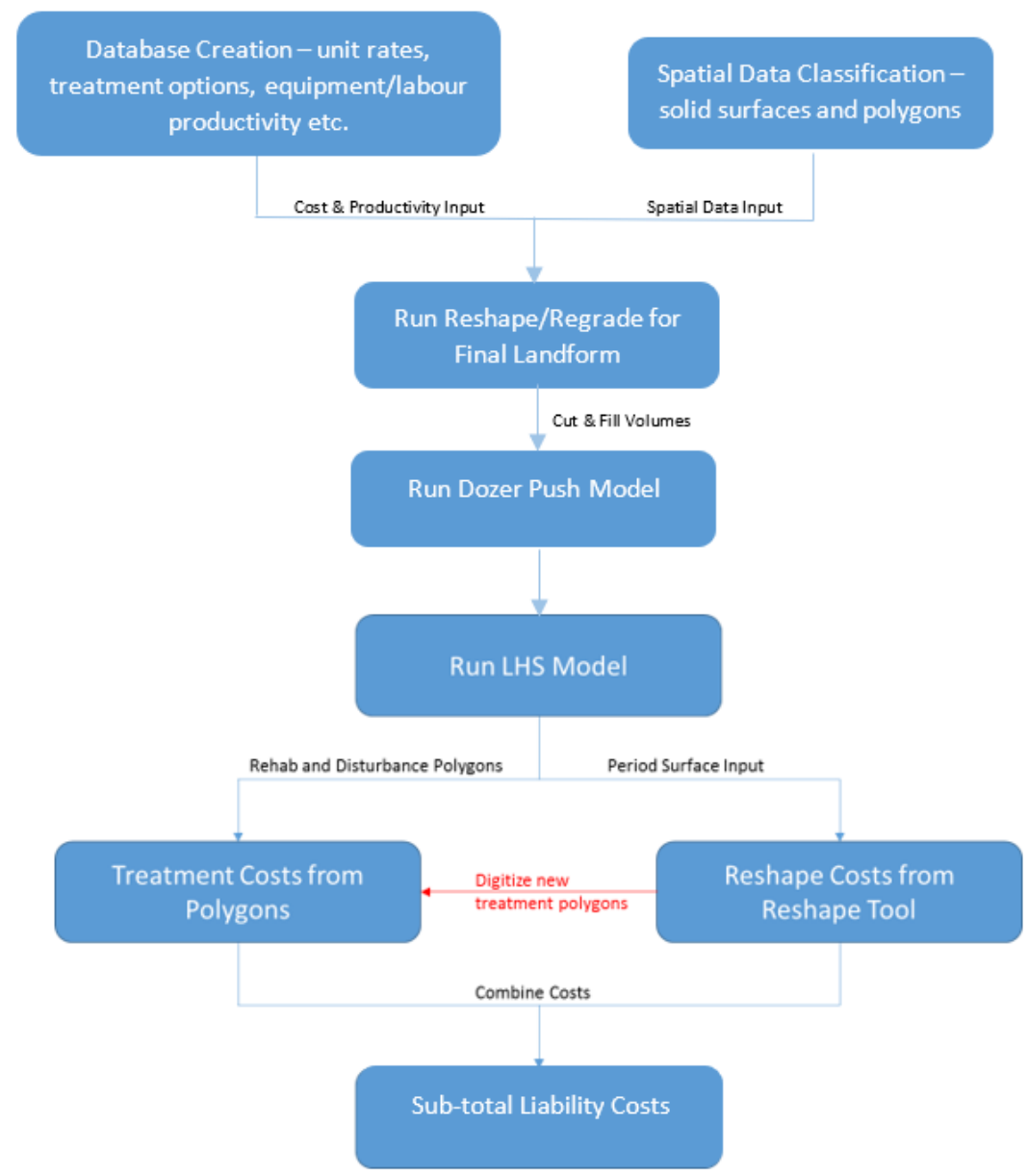

Figure 2 Process flow diagram of a spatial data-based closure costing model

The details of the process flow of the costing model are discussed in the following section. 


\subsection{Process flow}

The 3D spatial data of a mine site provides an accurate measurement of its topography; therefore, two key inputs are required for the costing model: the area polygons to estimate the remediation or treatment requirements and the $3 \mathrm{D}$ solids to estimate the reshaping requirements.

The following process flow has been used to create a spatial data-based closure costing model for the Mogalakwena mine:

1. Database creation:

a. Prepare a database of the latest site-specific unit costs (e.g. infrastructure demolition rates, hourly labour changes and seed mix rates per kilogram), equipment costs (plant hire costs) and activity costs (e.g. revegetation, drainage/earth works, soil remediation and waste disposal).

b. Prepare a database of equipment and labour productivities including working calendars.

c. Prepare a database of all treatment (rehabilitation/remediation) options required to achieve the final closure criteria-the closure estimate includes costs for all physical works that the corporate entity will be responsible for undertaking in implementing the operation's closure plan.

2. Classification of spatial data: establish and identify the polygons and solids (3D surfaces bound by polygons from the digital terrain model (DTM)).

3. Regrade/reshape requirements for final landform - the cut-and-fill volumes (the material required to be cut from and filled into specific places) needed to achieve the desired landform can be calculated based on various criteria. For example, for the waste rock dumps (WRDs), it could be specific side slope angles, final shape or final bench width and free draining surface, or similar. Once the cut-and-fill volumes are estimated, they can be divided into the following two categories of earth movement:

a. Dozing volumes (i.e. the volumes to be moved using a dozer)-these can be calculated by simulating cut blocks to be filled by the dozer into the shortest fill blocks. The shortest distance depends on specific dozer productivity (loose cubic yards (LCY) or loose cubic metres $\left(\mathrm{Lm}^{3}\right)$ per hour) versus the push distance as the dozer productivity significantly reduces for the longer push distances. In practice, a D11-equivalent dozer can have an economical push distance between $100 \mathrm{~m}$ and $150 \mathrm{~m}$ in hard rock type material movement (Caterpillar 2017).

b. Load and haulage - the material volumes that cannot be economically moved using dozers can be assigned for load and haul using trucks and shovels. Deswik CAD has the Landform and Haulage Simulator (LHS) model that enables the establishment of a full load and haul schedule for the given material movement and truck/shovel fleet.

c. Re-establish and update the surface area polygons based on reshaped final landform-once the mine site surface has been reshaped to achieve the final landform, it will have a new set of area polygons.

4. Growth media/topsoil sequencing: establish topsoil placement sequence and schedule-post completion of final landform reshaping, an optimised load and haul schedule needs to be established to place the topsoil on the areas requiring rehabilitation or revegetation.

5. Regrade and final cost estimate-equipment hours are calculated for both main and ancillary equipment, and the hourly/monthly cost rates are applied to estimate the regrade costs. In addition, the area-based treatment methods and related costs are calculated to establish the total closure costs of achieving final landform.

This is an iterative process, and various parameter settings and scenarios can be executed to establish the most suitable and cost-effective closure option for a given mine site. 
In the closure costing model, owner's management costs (also referred to as preliminary and general costs) or those costs that will be incurred by the corporate entity in supporting the closure program (security, site establishment, accommodation, messing and management etc.) can also be estimated once the equipment and labour requirements are finalised to implement the required closure plan (Botha 2013). In case of the Mogalakwena closure costing model, it has been assumed that the mining and earthworks contractors will be available to undertake all closure earthworks as required by the site mine closure plan and no specialist earthworks contractors will required to be mobilised to the site.

Post-closure costs-including environmental maintenance, monitoring and reporting, rehabilitation maintenance and lease payment costs-can be separately calculated based on the final closure phase schedule (output of the closure costing model) and the required specialist studies (e.g. subsidence, groundwater impact, tailings stability, land erosion studies and rehabilitation trials).

\section{Case study}

Mogalakwena is an open pit platinum mine wholly owned by Anglo American Platinum Ltd, a subsidiary of Anglo American PLC. It is a fully developed mine situated on the north-eastern limb of the Bushveld Complex in the Limpopo Province of South Africa. The mine was established in 1993 and has more than 50 years of life remaining. It currently employs approximately 5,000 people, including permanent employees and contractors. The mine produces platinum-group metals (PGMs), such as platinum, rhodium, palladium and some trace base metals. Platinum is the major commodity being produced at an average rate of 360,000 ounces per year. The mine consists of four different operational units: open pit mining area with several WRDs; two concentrators and associated tailings storage facilities (TSFs); and support services including offices, workshops and changing facilities. The Mogalakwena mine boundary area stretches over $8 \mathrm{~km}$ from east to west and approximately $13 \mathrm{~km}$ from north to south (Figure 3 ).

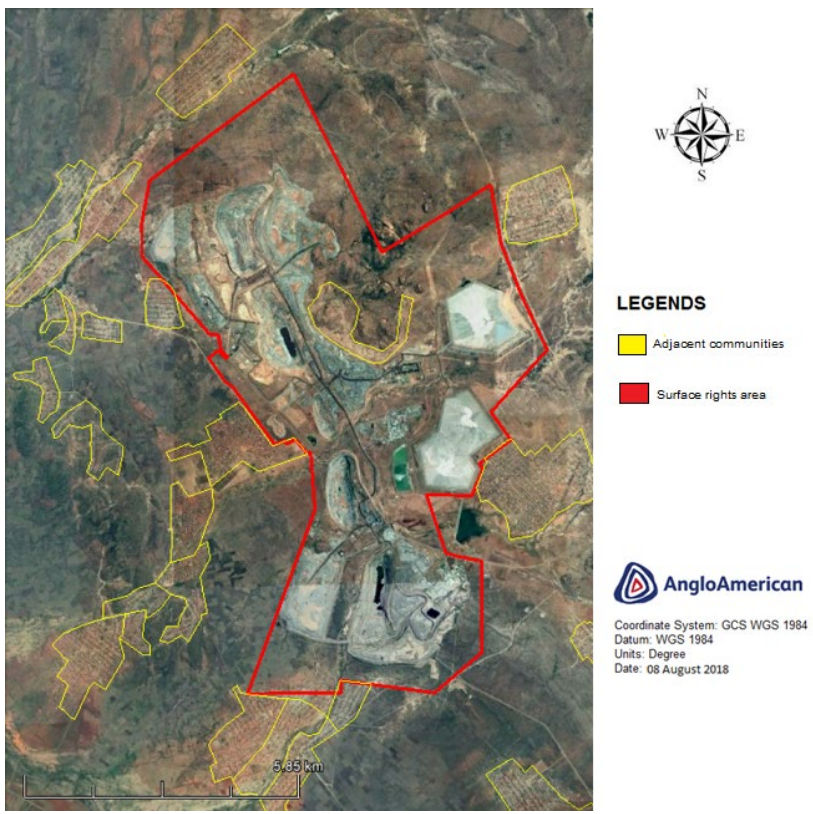

Figure 3 Study area: Mogalakwena open pit platinum mine (Anglo American)

\subsection{Constraints and opportunities using the ICPS}

Mogalakwena is an open pit operation, so the majority of closure costs relate to mineral waste. Currently, the ore to waste (rock) ratio is approximately one to six, which means that the mine needs to mobilise six tonnes of waste rock to get to one tonne of ore. Therefore, the mineral waste (tailings and waste rock) covers a significant portion of the mine surface rights area. The available space to place the mineral waste is constrained due to the presence of proximal communities in and around the surface rights area (Figure 3 ). The spatial constraints have driven the mine to utilise any available spaces for waste placement, resulting in 
suboptimal waste rock placement with steeper side slopes (at the angle of repose) and less than ideal bench widths $(<10 \mathrm{~m})$. This in turn drives the lack of reshaping opportunities for concurrent rehabilitation. The suboptimal waste rock placement requires significant reshaping to achieve the final rehabilitation slopes on WRDs. Therefore, establishing accurate rehabilitation costs of mine residue deposits not only drives the final liability estimate but also has significant impact on concurrent rehabilitation. Therefore, as an outcome of the ICPS opportunity workshop held at Mogalakwena in early 2017, a key identified opportunity was to undertake a detailed review of the current closure costs using a spatial data-based costing model (Grant et al. 2018).

\subsection{Spatial data analysis-closure cost model}

Using the Enviro module (and costing process map) and Deswik CAD, a spatial database was created for the entire Mogalakwena mine operations, including mining infrastructure, open pits, mine residues sites, stockpiles and service infrastructure. Two separate spatial databases were created for existing disturbances and the LoM (current and planned) disturbances. The outcome of the analyses has been detailed in the following sections.

\subsubsection{Immediate closure liability}

\subsubsection{Database creation}

The key task in creating a robust model is to create a reliable and accurate database of different inputs. An example of treatment activities generated using the process map is provided below (Table 1). Accurate costing estimates were generated by applying costs per hectare for the different activities. In addition, a database was prepared for equipment, labour productivity and specific unit costs.

Table 1 Example of a database created for various treatment options relevant to the mine site

\begin{tabular}{|c|c|c|c|c|c|c|}
\hline $\begin{array}{l}\text { Category } \\
\text { domain }\end{array}$ & Status & Aspect & Ripping & Vegetation & Drainage & $\begin{array}{l}\text { Ongoing } \\
\text { maintenance }\end{array}$ \\
\hline Clearance & Disturbed & Uncontaminated & $\begin{array}{l}\text { Rip and } \\
\text { seed }\end{array}$ & $\begin{array}{l}\text { Manual native } \\
\text { vegetation }\end{array}$ & $\begin{array}{l}\text { Minor } \\
\text { drainage }\end{array}$ & $\begin{array}{l}\text { Minor } \\
\text { maintenance }\end{array}$ \\
\hline $\begin{array}{l}\text { Current } \\
\text { stockpiles }\end{array}$ & Disturbed & $\begin{array}{l}\text { Contaminated } \\
\text { minor }\end{array}$ & $\begin{array}{l}\text { Rip and } \\
\text { seed }\end{array}$ & $\begin{array}{l}\text { Manual native } \\
\text { vegetation }\end{array}$ & $\begin{array}{l}\text { Moderate } \\
\text { drainage }\end{array}$ & $\begin{array}{l}\text { Moderate } \\
\text { maintenance }\end{array}$ \\
\hline Dam & Disturbed & $\begin{array}{l}\text { Contaminated } \\
\text { minor }\end{array}$ & $\begin{array}{l}\text { Rip and } \\
\text { seed }\end{array}$ & $\begin{array}{l}\text { Manual native } \\
\text { vegetation }\end{array}$ & $\begin{array}{l}\text { Minor } \\
\text { drainage }\end{array}$ & $\begin{array}{l}\text { Minor } \\
\text { maintenance }\end{array}$ \\
\hline $\begin{array}{l}\text { Dust aside } \\
\text { road }\end{array}$ & Disturbed & $\begin{array}{l}\text { Contaminated } \\
\text { minor }\end{array}$ & $\begin{array}{l}\text { Rip and } \\
\text { seed }\end{array}$ & $\begin{array}{l}\text { Manual native } \\
\text { vegetation }\end{array}$ & $\begin{array}{l}\text { Minor } \\
\text { drainage }\end{array}$ & $\begin{array}{l}\text { Minor } \\
\text { maintenance }\end{array}$ \\
\hline Gravel roads & Disturbed & $\begin{array}{l}\text { Contaminated } \\
\text { minor }\end{array}$ & $\begin{array}{l}\text { Rip and } \\
\text { seed }\end{array}$ & $\begin{array}{l}\text { Manual native } \\
\text { vegetation }\end{array}$ & $\begin{array}{l}\text { Minor } \\
\text { drainage }\end{array}$ & $\begin{array}{l}\text { Minor } \\
\text { maintenance }\end{array}$ \\
\hline Infrastructure & Disturbed & $\begin{array}{l}\text { Contaminated } \\
\text { minor }\end{array}$ & $\begin{array}{l}\text { Rip and } \\
\text { seed }\end{array}$ & $\begin{array}{l}\text { Manual native } \\
\text { vegetation }\end{array}$ & $\begin{array}{l}\text { Minor } \\
\text { drainage }\end{array}$ & $\begin{array}{l}\text { Minor } \\
\text { maintenance }\end{array}$ \\
\hline $\begin{array}{l}\text { Oxidised } \\
\text { stockpile }\end{array}$ & Disturbed & $\begin{array}{l}\text { Contaminated } \\
\text { minor }\end{array}$ & $\begin{array}{l}\text { Rip and } \\
\text { seed }\end{array}$ & $\begin{array}{l}\text { Manual native } \\
\text { vegetation }\end{array}$ & $\begin{array}{l}\text { Moderate } \\
\text { drainage }\end{array}$ & $\begin{array}{l}\text { Moderate } \\
\text { maintenance }\end{array}$ \\
\hline Tailings & Disturbed & $\begin{array}{l}\text { Contaminated } \\
\text { minor }\end{array}$ & $\begin{array}{l}\text { Rip and } \\
\text { seed }\end{array}$ & $\begin{array}{l}\text { Manual native } \\
\text { vegetation }\end{array}$ & $\begin{array}{l}\text { Minor } \\
\text { drainage }\end{array}$ & $\begin{array}{l}\text { Minor } \\
\text { maintenance }\end{array}$ \\
\hline Tar roads & Disturbed & $\begin{array}{l}\text { Contaminated } \\
\text { moderate }\end{array}$ & $\begin{array}{l}\text { Rip and } \\
\text { seed }\end{array}$ & $\begin{array}{l}\text { Manual native } \\
\text { vegetation }\end{array}$ & $\begin{array}{l}\text { Minor } \\
\text { drainage }\end{array}$ & $\begin{array}{l}\text { Minor } \\
\text { maintenance }\end{array}$ \\
\hline WRD & Disturbed & $\begin{array}{l}\text { Contaminated } \\
\text { minor }\end{array}$ & $\begin{array}{l}\text { Rip and } \\
\text { seed }\end{array}$ & $\begin{array}{l}\text { Manual native } \\
\text { vegetation }\end{array}$ & $\begin{array}{l}\text { Moderate } \\
\text { drainage }\end{array}$ & $\begin{array}{l}\text { Moderate } \\
\text { maintenance }\end{array}$ \\
\hline
\end{tabular}




\subsubsection{Classification of spatial information}

The spatial data received for the site was high resolution $(<1 \mathrm{~m})$ and can pose challenges in terms of extensive processing time and resources. Therefore, the spatial data were reduced to $5 \mathrm{~m}$ resolution. The data were further classified into polygons and solid surfaces with the available site imagery and other information (Figures 4 and 5). The polygons are essential to define the extent of classified infrastructure, such as buildings, roads, open pits, WRDs and TSFs. These polygons are then used to create 3D surface models for the specific infrastructure areas referred to as solids. The polygons are further classified into the type of closure action/treatment they require-such as demolition, ripping, drainage, topsoiling and revegetation-and therefore referred to as treatment polygons.
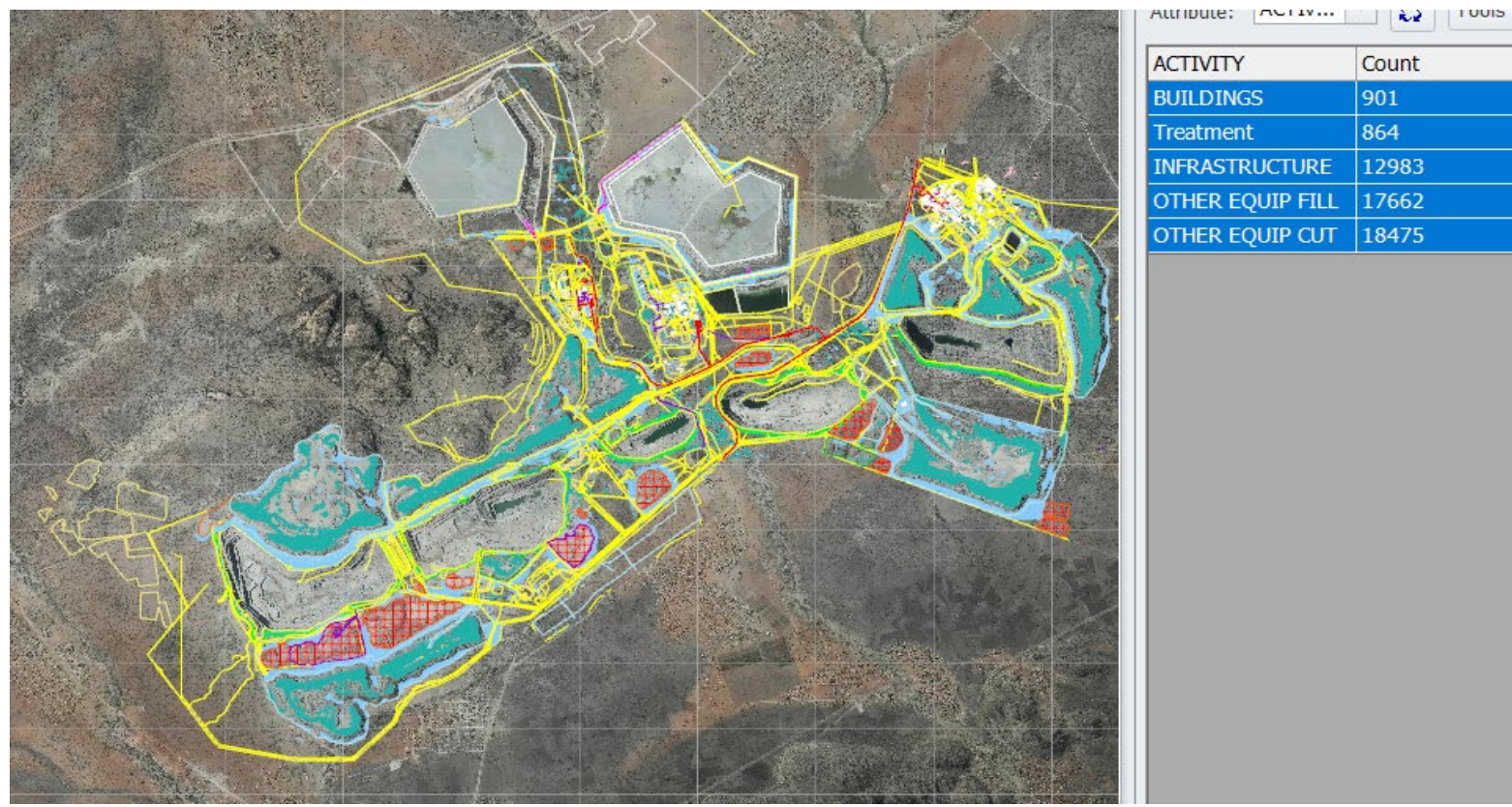

Figure 4 The study area characterised in various polygon shapes-existing (2017) disturbances

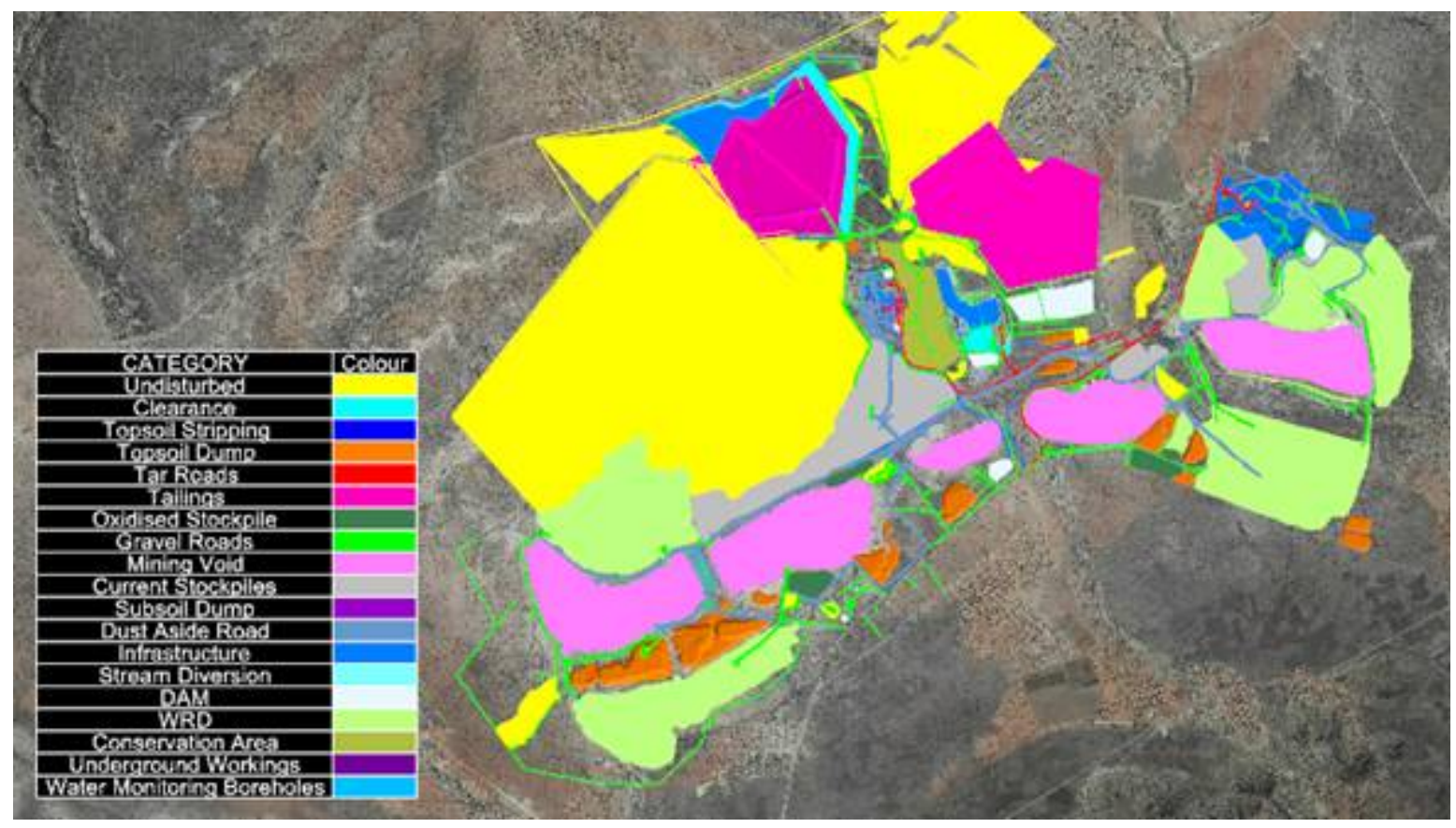

Figure 5 The study area characterised in 3D surfaces (solids)—existing (2017) disturbances 


\subsubsection{Regrade volume estimate}

Once the solids are classified, the reshape tool built in Deswik Enviro was used to reshape the required surfaces, such as WRDs, TSFs and disturbed land to their final rehabilitation angles. The reshape tool gives an estimate of the cut-and-fill volumes required to be moved to achieve the final landform. Multiple reruns of the tools are required to achieve a satisfactory final landform design that has a good cut-and-fill balance, which means that there are sufficient fill volume areas for the estimated cut volumes within a reasonable distance. These cut-and-fill volumes are further classified into the volumes that can and cannot be moved using dozers based on dozer productivity, as longer dozer pushes become more expensive than truck and shovel operations. For this exercise, a $200 \mathrm{~m}$ dozer push distance was used as cutoff for D11R-equivalent dozers based on internal benchmarking. The remaining cut volumes that cannot be pushed using dozers will be moved using trucks and shovels (Figure 6). The LHS module in Deswik CAD allows for creating a trucking cycle time estimates that, in turn, are used in calculating equipment hours.

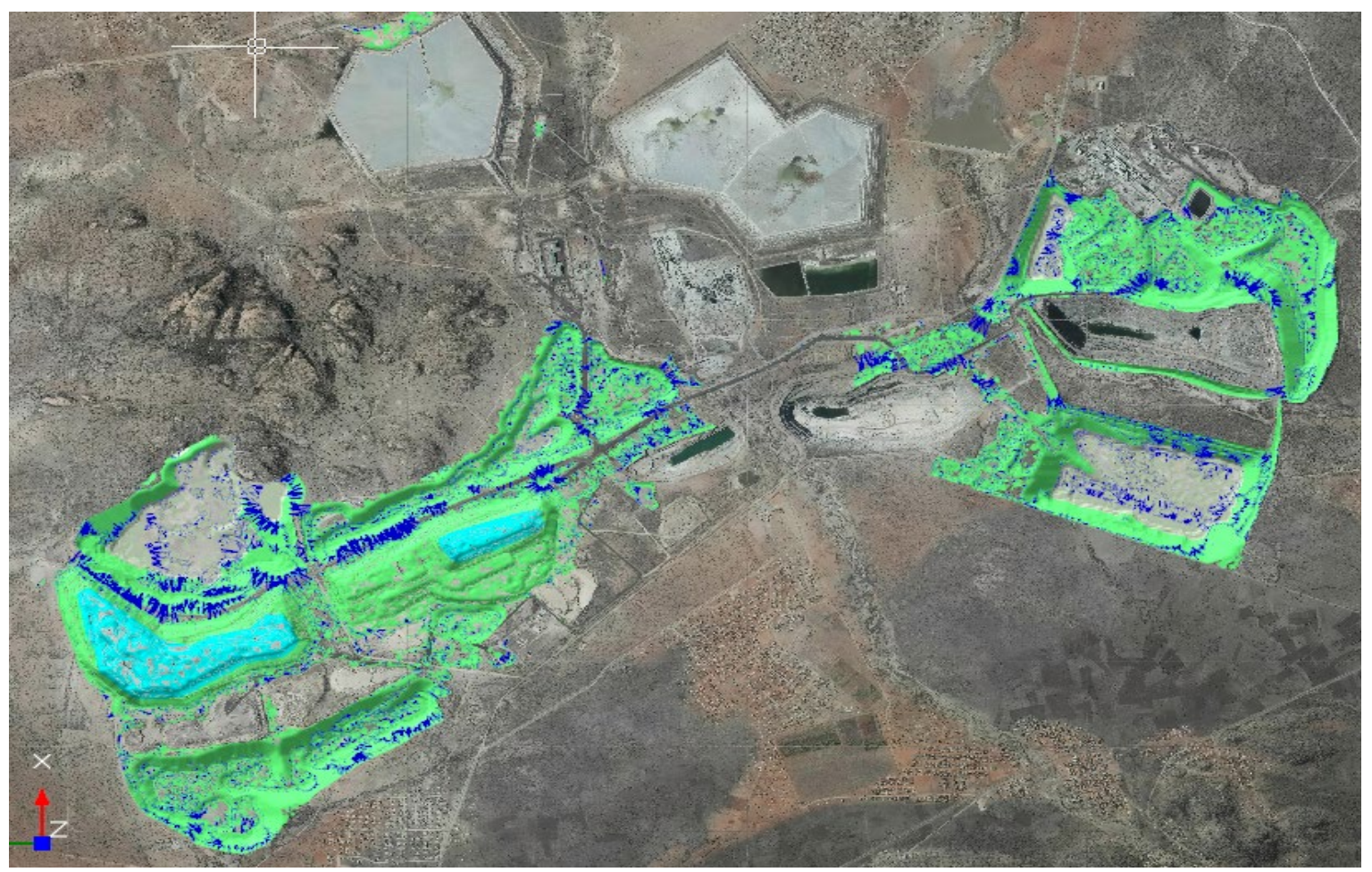

Figure 6 Final reshaped surface with cut (green) and fill (light blue) volumes, dozer push lines (dark blue)—existing (2017) disturbances

\subsubsection{Growth media/topsoil sequencing}

The treatment polygons were revised for the regraded final landform. A topsoil depletion schedule from stockpiles to disturbed areas requiring topsoiling was established using the LHS model (Figure 7). Based on the equipment hours and treatment polygon areas, the final closure cost for immediate closure was calculated by applying the unit rates to the estimated quantities. 


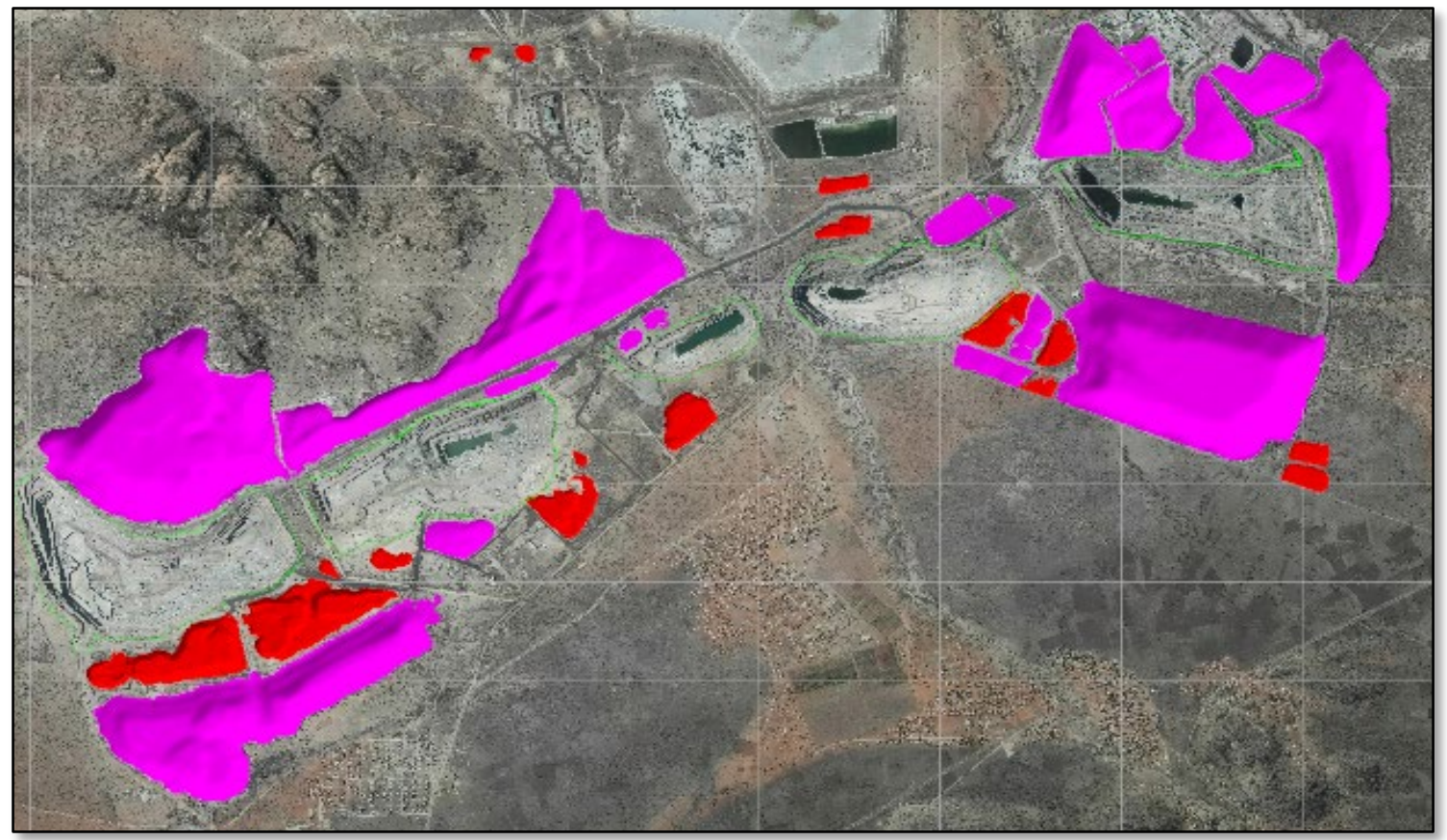

Figure 7 Topsoil placement: topsoil stockpiles (red) and areas requiring placement (pink)—existing (2017) disturbances

\subsubsection{LoM closure liability}

The same process that was used to calculate the immediate liability costing was followed for the LoM closure cost for the Mogalakwena mine. In this case, the end of life (current and planned disturbances) surface model was used to achieve the final landform design. Figures 8 and 9 illustrate the final regraded surface for the LoM surface model.

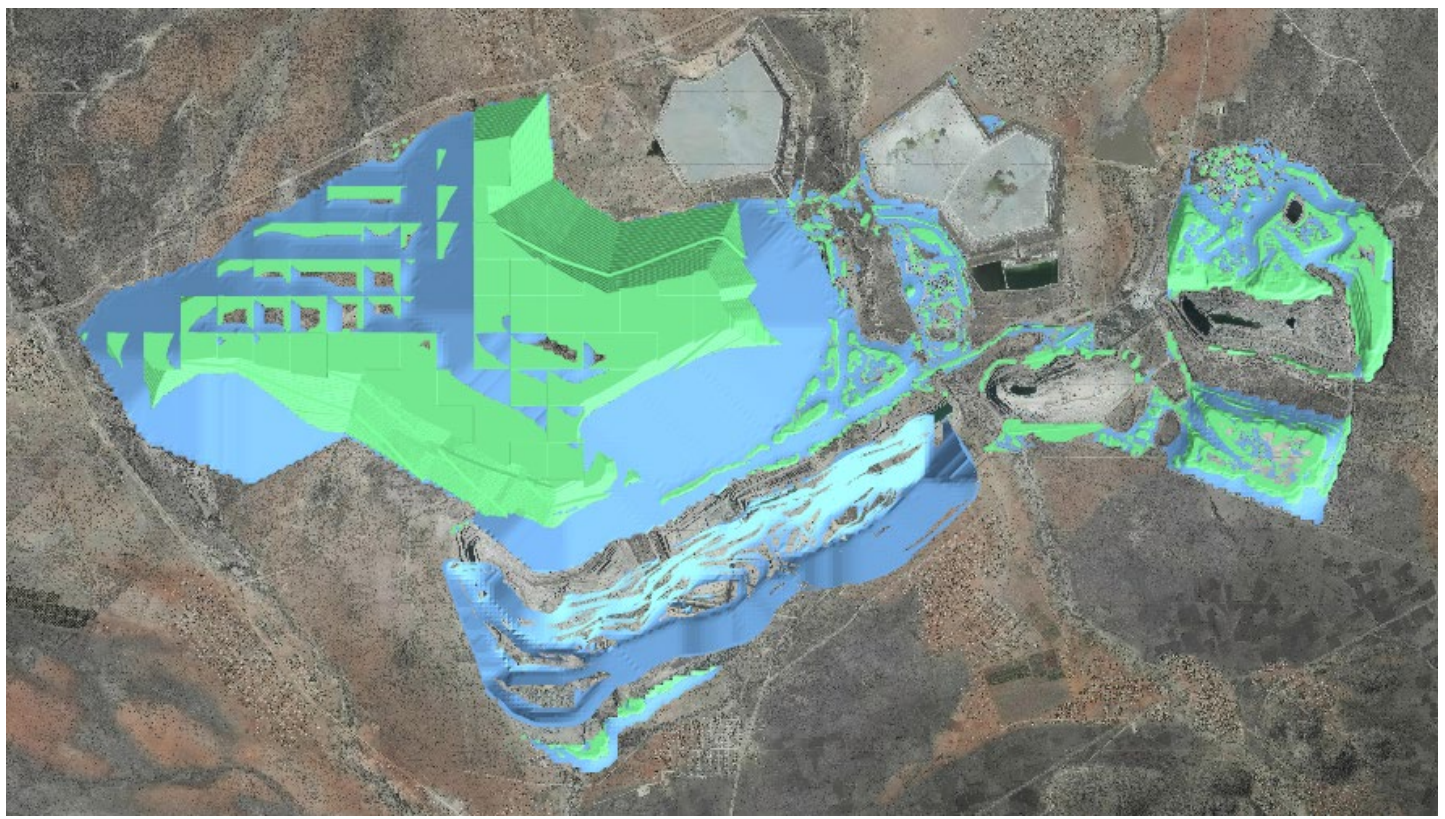

Figure 8 Cut (green) and fill (blue) volumes-LoM disturbances 


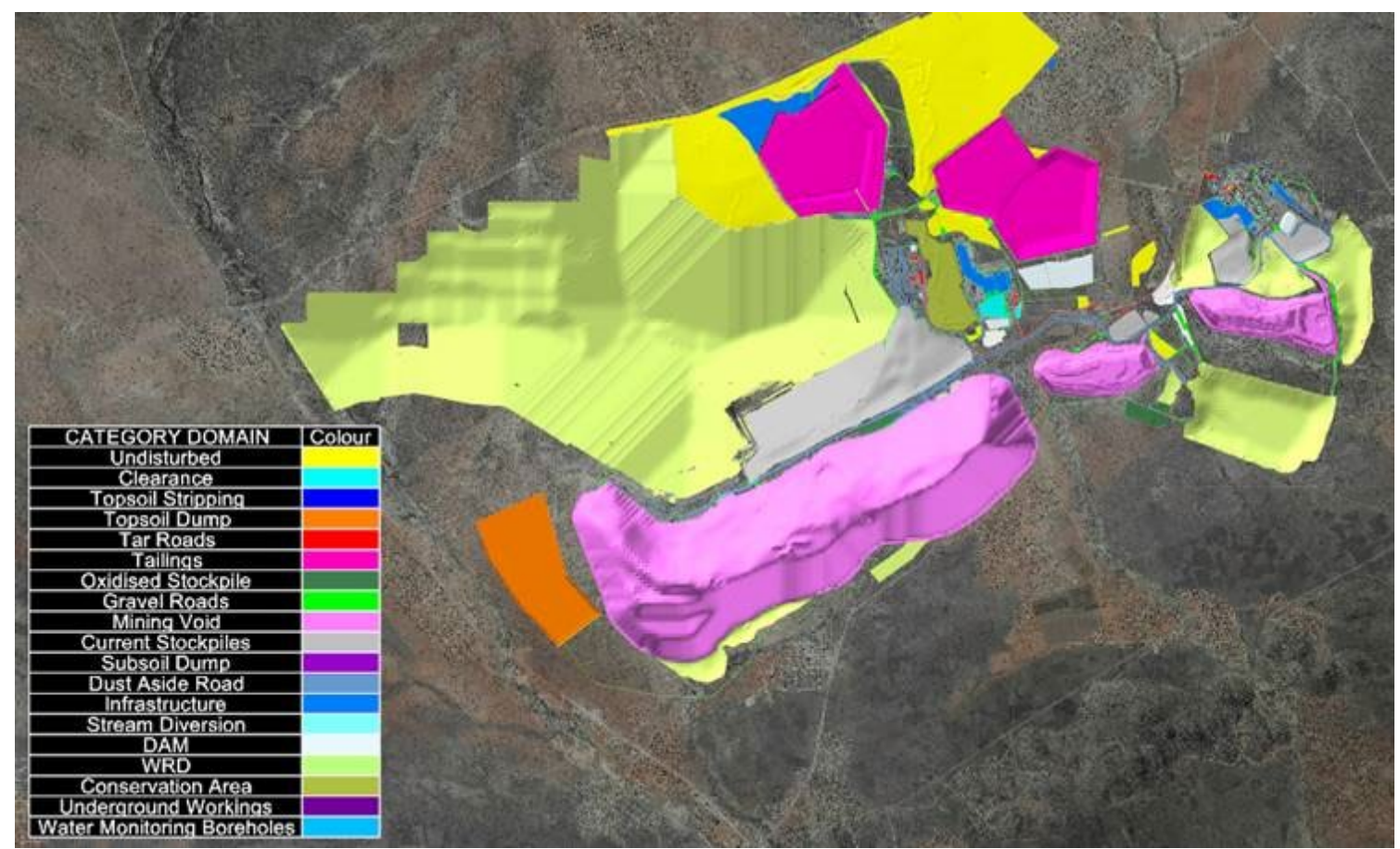

Figure 9 Final reshaped surface-LoM disturbances

\subsection{Results}

\subsubsection{Accurate closure cost estimate and opportunities identified}

The overall closure cost for immediate closure (2017) was significantly higher than the previous estimate undertaken using conventional methods. The largest portion of the immediate closure liability consisted of reshape (dozer and load and haul) and surface rehabilitation costs. Using conventional methods, the WRDs rehabilitation cost was also the main contributor to the total liability; however, almost all the reshaping of WRDs was assumed to be undertaken using only dozers. In addition, the cut-and-fill volumes were estimated to be significantly more (almost double) than the previous estimates. Therefore, the previous liability estimate was significantly understated.

This exercise established that the mine residue (WRDs and TSFs) rehabilitation made up about $70 \%$ of the total closure liability in case of premature or immediate closure and almost $90 \%$ in case of planned or LoM closure (Figure 10). In both immediate and LoM closure cases, the load and haul costs were significantly more than the dozing costs and were the major contributor to the reshape costs, indicating suboptimal placement of waste rock (i.e. restricted footprint, smaller bench widths, steeper side slopes and high dump heights).

In addition to the significant regrade costs, the suboptimal waste placement could also contribute to other environmental issues-such as dust, erosion and groundwater impacts-leading to increased post-closure costs due to active care and maintenance requirements. Since a significant portion of a mine's life is remaining, approximately $60-70 \%$ of waste rock will still be required to be placed over the remaining LoM. This immediately indicated an opportunity to reconsider the waste placement plan over the remaining LoM, such that the cut-and-fill requirements to achieve the final rehabilitation angles could be significantly reduced and therefore reducing the LoM reshape costs significantly. 


\section{Immediate Closure Costs}

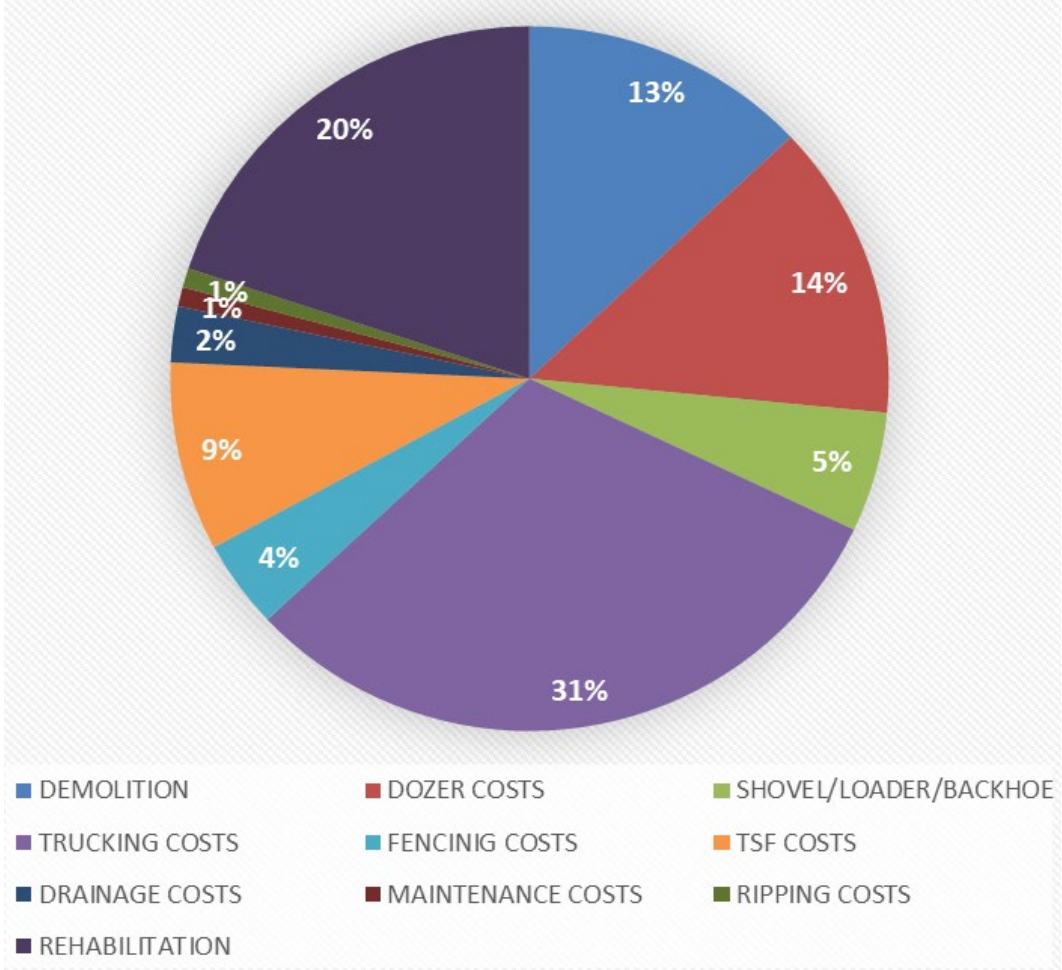

(a)

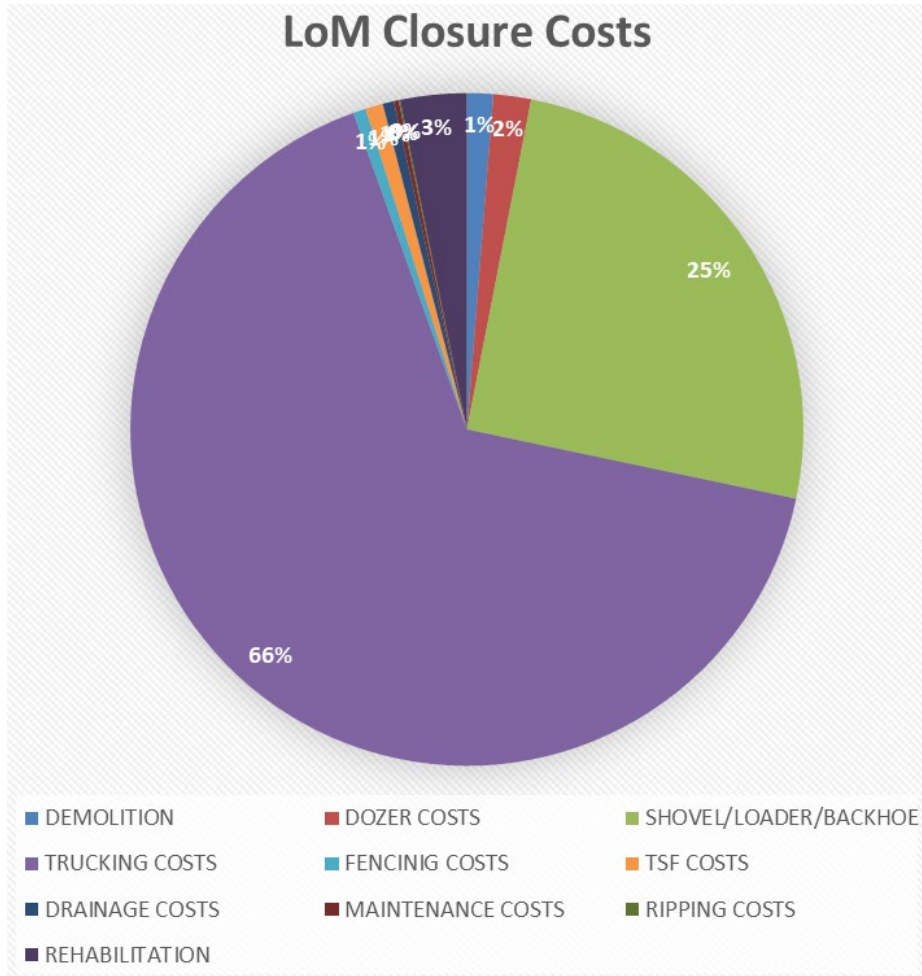

(b)

Figure 10 Immediate closure (a) and LoM (b) closure costs (2017)—key cost categories 


\subsubsection{Owner's costs estimated}

The resource allocation optimisation built in the costing model allowed the establishment an optimal fleet of trucks, shovels, dozers and other auxiliary equipment required to achieve the final closure surface at Mogalakwena. The equipment operating labour, earthworks, security, specialists and other overhead requirements were estimated given the size and duration of the closure operation. The owner's costs (preliminary and general) were found to be about $25 \%$ of the overall liability.

\subsubsection{Growth media and rehabilitation costs}

It is difficult to accurately measure the area of the sloped and irregular surfaces using conventional cartographic methods or aerial images. Three-dimensional spatial data provides an accurate estimate of areas requiring treatment (topsoil, amelioration, revegetation and maintenance etc.). Therefore, a better estimate of surface areas of various landform components (WRDs, TSFs and general surfaces etc.) contributed to an accurate estimate of treatment costs.

In addition, it was established the mine had sufficient growth media (topsoil and subsoil combined) stockpiles to cater for all rehabilitated surfaces requiring revegetation. The mine was previously assumed to be deficient in growth media required to achieve final landform.

\section{$4 \quad$ Discussion and future opportunities}

This exercise assisted in review and optimise WRD placement strategy to ensure dumping to final rehabilitation angles wherever possible and enabled the focus on long-term concurrent rehabilitation strategy to reduce the LoM liability.

\subsection{Model update}

Since completion of this study in 2018, a revised waste placement strategy/plan has been developed. The revised strategy ensures sufficient bench width is left between the consecutive WRD lifts in the waste placement plan over the remaining life of operation to allow for future flattening of side slopes. In addition, the new strategy utilises some of the unused or already impacted areas to place the waste rock in much shallower dumps at gentler slopes $\left(<20^{\circ}\right)$ as opposed to angle of repose $\left(>35^{\circ}\right)$. The waste rock will now be placed higher at shorter haul distances (inner sides of the mine site), gradually lowering the slopes away for longer haul distances (outer sides of the mine site).

A preliminary analysis of closure cost impact of the new strategy indicates significant reduction in the LoM reshaping cost (especially the north dump) as fewer slopes close to the pits will require any significant reshaping. In addition, due to increased bench widths and shallow slope angles, the volumes of material requiring the load and haul will be reduced significantly.

Figure 11 illustrates the comparison of reshaping costs $\left(Z A R / \mathrm{m}^{2}\right)$ heat map for both 2017 (old) and 2018 (revised) waste placement plan. The heat map comparison clearly shows that altering the old waste rock placement plan results in significantly lower reshaping costs for the WRDs. 


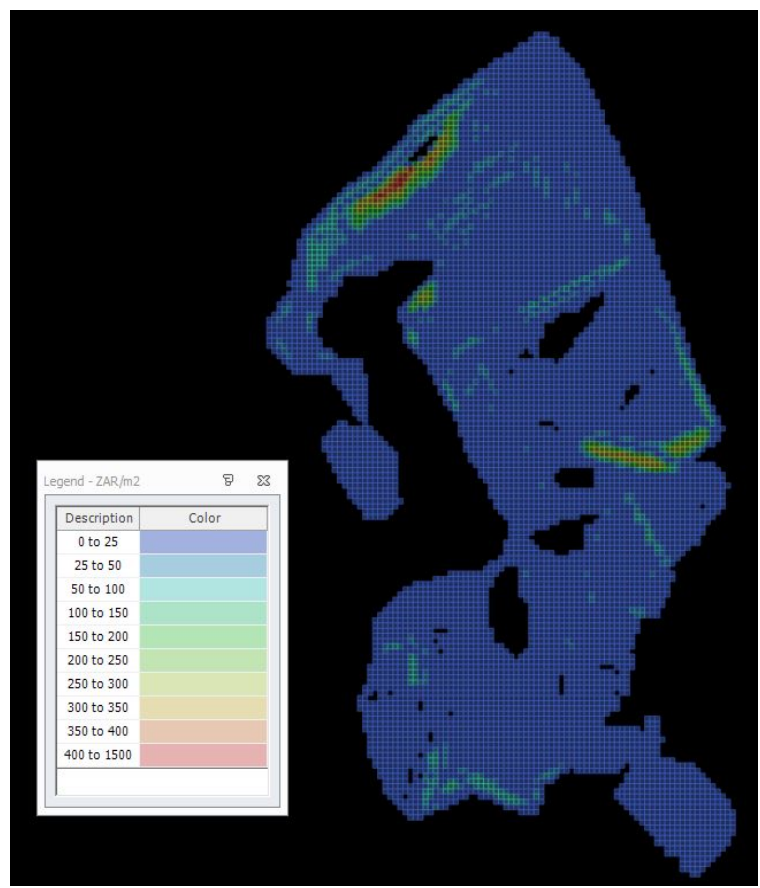

(a)

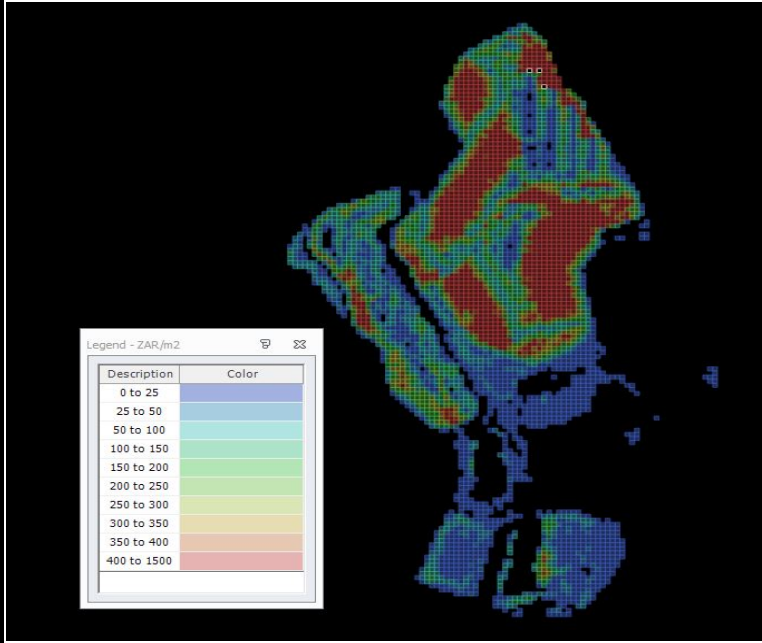

(b)

Figure 11 Reshape cost heat map $\left(\mathrm{ZAR} / \mathrm{m}^{2}\right)$ comparing the revised (2018) LoM waste placement plan (a) with the old (2017) LoM waste placement plan (b)

\subsection{Future opportunities}

For complete value realisation of the ICPS, further opportunities have been identified that would require the LoM plan update to bring forward the concurrent rehabilitation of the WRDs and TSFs in the mine operations lifecycle to significantly reduce the closure costs at the end of LoM.

\section{Conclusion}

Financials are one of the core elements of the ICPS, and the system requires that the closure cost estimation is established as accurately as possible early in the life of an operation. A spatial data-based closure costing model enables detailed and accurate closure cost estimates by simulating the real-life landform reshaping scenarios with the available resources and their productivities. To summarise, the model provides following benefits over a conventional closure costing approach. The Mogalakwena case study demonstrated that such a costing tool can be very useful in identifying the key closure cost drivers with reasonably accurate closure cost estimation. As a result, it can enable better decision-making through integrated closure planning. Key learnings of our case study follow:

- For a surface mining operation, the cost of successfully achieving the final landform at closure can be significant if the final landform optimisation has not been considered at the mine planning stage. Since the disturbed surfaces of the mining operations can be reworked in a spatial data-based platform, it can be a valuable tool in optimising and estimating the cost of final landform design. The main advantage of such a model over other conventional methods is the accurate estimation of key input parameters (volumetric quantities, area-based measurements, equipment efficiency and labour productivity etc.) to a costing model influencing the accuracy of final closure cost estimates.

- Multiple scenario analyses provide an advantage of a convenient integration with the LoM planning processes. 
- The modelling process is a first principles approach, meaning the impact of any changes in the input parameters (e.g. unit rates, equipment or labour productivity and treatment costs) can be easily tracked on the overall cost, ensuring transparency and auditability of the model.

- The model can assist in creating a comprehensive land management plan over the life of operation (with concurrent rehabilitation) supporting a sustainable end land use.

- Like any model, a spatial data-based costing model will be as good as the quality of its inputs and the robustness of its process flow. Therefore, creation of a successful costing model would require a multidisciplinary input, such as software specialists, the mine personnel in the fields of mine planning and environmental management.

- Once the baseline model is developed, subsequent updates of the model can create a valuable spatio-temporal database demonstrating the evolution of site-specific closure planning.

\section{Acknowledgement}

The authors acknowledge the following teams for their contributions to this project: the Anglo American Group Technical and Sustainability Team (Carl Grant, Rudolph Botha, Hermanus Prinsloo, Erich Heymann, Stuart Rech and Scott Buchanan), the Platinum Corporate and Site Team (Wilma Combrink, Richard Cox, Hendrik van Heerden, Frans Marais, Allan Hartley, Marlon van Heerden, Mick Angliss), and the Deswik South Africa Team.

\section{References}

Bocking, KA 2010, 'Post-closure liabilities', Australian Centre for Geomechanics Newsletter, vol. 35, pp 20-23.

Botha, PR 2013, Mine Closure Toolbox, Anglo American PLC, Johannesburg.

Caterpillar 2017, Caterpillar Performance Handbook 2017, 47th edn, Caterpillar, viewed 1 August 2019, https://www.albancat.com/content/uploads/2017/08/SEBD0351_ED47.pdf

Grant, CD \& Lacy, HWB 2016, 'Developing Anglo American's integrated closure planning system requires people, process and technology working together', in AB Fourie \& M Tibbett (eds), Proceedings of the 11th International Conference on Mine Closure, Australian Centre for Geomechanics, Perth, pp 581-594.

Grant, CD, Slight, M \& Lacy, HWB 2018, 'Integrated closure planning systems: a structured approach to opportunities analysis creates significant value', in J Wiertz \& D Priscu (eds), Proceedings of Planning for Closure 2018, Gecamin, Santiago.

Haymont, R 2012, Closure Cost Estimating Methodologies: A Review of Mine Closure Cost Estimating Methodologies for Different

Reporting Purposes, Trajectory, Subiaco, viewed 8 March 2019, http://www.trajectory.net.au/documents/2012\%20\%20Closure\%20Cost\%20Estimating\%20Liabilities\%20-\%20GEMG.pdf

International Council on Mining and Metals 2008, Planning for Integrated Mine Closure Toolkit, International Council on Mining and Metals, London.

Slingerland, N \& Wilson, GW 2015, 'End land use as a guide for integrated mine planning and closure design', Proceedings of the Tenth International Seminar on Mine Closure, InfoMine Inc., Vancouver, pp. 235-248. 